\title{
SILICON SAVANNAH - INNOVATION ECOSYSTEMS OF AFRICA WITH A SPECIAL REGARD TO KENYA
}

\author{
Szabolcs Szolnoki ${ }^{1}$ \\ Árpád Papp-Váry
}

DOI: https://doi.org/10.31410/ITEMA.2019.149

\begin{abstract}
In Africa, where 60\% of the population is under 25 years, the enormous and diverse business environment suffers from a number of problems, ranging from access to funding to gaps in government support and weaknesses in the education system. Undoubtedly, there is the need for better governance among the continent's nations in order to catch up and to develop creative economies with high added value products. Considering Kenya, the information and communication industry can be a breakthrough point thanks to positive, "enabler regulation" and governmental support. The authors believe that the IT sector could serve as an "escape card" from the captivity of history and geography. Astonishingly, 85\% of the population is employed in agriculture while the country is called "Silicon Savannah". 43 financial institutions, around 1000 startups and an emerging FinTech ecosystem can be identified with several dominant Chinese and Indian corporates. Furthermore, Google, IBM and other tech multinationals are also present. IBM opened its 12th development center in Nairobi, Kenya's capital found in 1899 with a current population of 5.6 million. Large technology companies are promoting business and idea competitions across the continent in the field of internet and communication technologies. Since half of the $580.367 \mathrm{~km} 2$ country is arid or semi-arid, the Kenyan market is also interesting for foreign AgriTech companies besides the IT industry. It is indisputable that large companies cannot replace the government in creating the basis of a prosperous business environment, nonetheless they do have a beneficial effect on the building of networks and providing opportunities for ideas to emerge. Universities can achieve similarly positive results. The Stanford alumni network has already been successful in Africa. By the coordinated activities of former students outside California the organization creates jobs, generates revenue, and has a positive social impact. Kenya has undergone significant political, structural and economic reforms over the past decade, largely contributing to sustainable economic growth and social development. The August 2010 Constitution introduced a new system of political and economic governance that promoted a greater level of investments, strengthened accountability and the development of local public services. Forecasts for the near future show that GDP growth is expected to rise to 5.8 percentage points in 2019, supported by a boom in agriculture, a more favourable business climate and a reduction of political uncertainty. In the medium term, GDP growth is projected to 6\% in 2020, depending on private sector credit growth, ongoing remittances, debt and expenditure management and global oil prices. However, the main challenges are still poverty, inequality, climate change, economic exposure and vulnerability to internal and external shocks. Kenya has every chance of becoming a success story for Africa through its growing young population, dynamic private sector, highly skilled workforce, better infrastructure, new constitution and central role in East Africa. Key economic and social goals include reducing the poverty rate and inequality, improving governance, creating cohesion between market needs and educational curricula, adapting to climate change, achieving rapid and sustained growth in investment and corporate productivity.
\end{abstract}

Keywords: Kenya, African Startups, Innovation, Startup Savannah.

\footnotetext{
$1 \quad$ University of Pécs, Pécs, Ifjúság útja 6, 7624 Magyarország, Hungary

2 Budapest Metropolitan University, Budapest, Nagy Lajos király útja 1-9, 1148 Magyarország, Hungary
} 


\section{KENYA IN THE 21ST CENTURY - DEVELOPMENT GOALS}

$\mathrm{T}$ he eighty-five percent of the population works in agriculture; smallholder farming is widespread. Half of the country lies in an arid or semi-arid area, therefore advanced irrigation technologies, agricultural training programmes, organic products and materials, machines and equipment facilitating water retention offer a good opportunity to enter the Kenyan market nevertheless, European and non-European competitors are also present.

Forty-three financial institutions are registered in Kenya; therefore, it is also called Silicon Savannah. There are more than 1000 operating start-up enterprises and the FinTech (financial technology) industry plays a prominent role. The field is dominated by Chinese and Indian companies, but Google, IBM and other multinational IT companies are also present. IBM opened its 12th development centre in Nairobi, the capital of Kenya, founded in 1899, with a current population of approximately 5.6 million people. Google is active in Kenya and Northern Africa as well. Large technology enterprises in the field of internet and communication technologies announce business and idea competitions all around the continent. Large enterprises cannot perform governmental tasks required for the development of the business environment, but they do have a beneficial effect on the creation of a network of connections, giving room to the unfolding of ideas. Universities may achieve similarly positive results. For example, the cooperation of former students in the framework of the Stanford alumni network creates jobs, generates incomes and has a positive social impact outside California, and they have implemented successful projects in Africa as well.

Kenya has also implemented significant political, structural and economic reforms in the past decade, which mostly facilitated sustainable economic growth and social development. However, the most important challenges are still poverty, inequality, climate change and the exposure of the economy, its vulnerability by internal and external shocks.

Kenya's recent political reform originates from the adoption of the new constitution in 2010, which introduced bicameral legislature, decentralised county government, and judicial and electoral bodies authorized by constitution. As a result of the latest presidential election on 17 October 2017, President Uhuru Kenyatta started his second and final five-year term on 28 November 2017.

The constitution of August 2010 introduced a new system of political and economic governance with the aim of facilitating bigger investments, strengthening accountability and the building of public services at the local level.

While economic activity deteriorated after the 2008 global recession in economy, growth has gained new momentum in the past five years, reaching 5.7 percentage points in 2018. Economic growth has been facilitated by a stable macroeconomic environment, low oil prices, the boom of tourism, remittances and the government-led infrastructural development initiative.

According to forecasts for the near future, the increase of the gross domestic product (GDP) is expected to increase to 5.8 percentage points in 2019, which is fuelled by the boom of agriculture, a more favourable business climate and easing political uncertainty. In the medium term, the growth of the GDP must increase to 5.8 percentage points in 2019 and 6 percentage points in 2020, which depends on private sector credit growth, increasingly strengthening remittances, the management of public debt and spending, and global oil prices. 


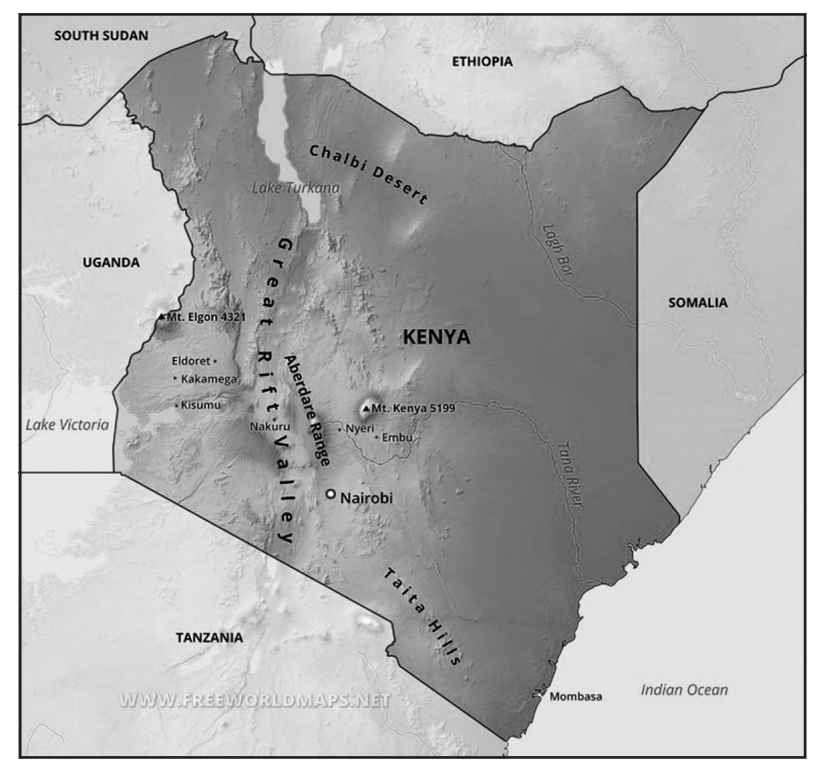

\section{General information}

Capital city: Nairobi

Area: $580.367 \mathrm{~km} 2$

Population: 44,4 million people

Currency: Kenyan shilling (KES)

Languages: Swahili, English

Figure 1: A map of Kenya. Source: Free World Maps

In the long term, the adoption of prudent macroeconomic policies helps to preserve Kenya's robust economic performance. This includes fiscal and monetary prudence and the reduction of the deficit to 4.3 percentage points for 2019/2020 according to the Medium-Term Expenditure Framework. The consolidation of the budget must avoid jeopardising state investments into critical infrastructure and economic production capacities.

Table 1. The most important economic indicators

\begin{tabular}{|l|c|c|c|c|c|c|c|}
\hline Name of indicator & $\begin{array}{c}\text { Unit of } \\
\text { measurement }\end{array}$ & $\mathbf{2 0 1 2}$ & $\mathbf{2 0 1 3}$ & $\mathbf{2 0 1 4}$ & $\mathbf{2 0 1 5}$ & $\mathbf{2 0 1 6}$ & $\mathbf{2 0 1 7}$ \\
\hline $\begin{array}{l}\text { Value of GDP } \\
\text { (current price) }\end{array}$ & Billion EUR & 100.22 & 107.83 & 115.64 & 123.58 & 132.50 & 141.48 \\
\hline Change of GDP (real) & $\%$ & 4.56 & 5.88 & 5.36 & 5.72 & 5.87 & 4.89 \\
\hline $\begin{array}{l}\text { Per capita GDP at } \\
\text { current prices }\end{array}$ & EUR/capita & 999.07 & 1064.80 & 1156.65 & 1173.91 & 1267.01 & 1306.26 \\
\hline Inflation (HICP) & $\%$ & 9.38 & 5.72 & 6.88 & 6.58 & 6.30 & - \\
\hline Unemployment rate & $\%$ & - & - & - & - & - & - \\
\hline Export value & Billion EUR & 9.71 & 9.51 & 9.74 & 9.20 & 8.58 & 9.04 \\
\hline Import value & Billion EUR & 15.52 & 15.85 & 17.57 & 15.31 & 13.99 & 16.53 \\
\hline FDI outflow & Billion EUR & 0.21 & 0.17 & 0.07 & 0.21 & 0.14 & 0.22 \\
\hline FDI inflow & Billion EUR & 1.20 & 0.97 & 0.71 & 0.54 & 0.34 & 0.58 \\
\hline
\end{tabular}

Source: Export Hungary

The long-term development plan appears in the so-called "Vision 2030" document announced by the president in December. The four major development priorities are: manufacturing, universal health care, affordable housing and food security.

Kenya has already met certain objectives outlined in the Millennium Development Goals (MDG). The country has achieved results in the reduction of child mortality, increasing the enrolment ratio in primary education, and closing the gender pay gap in education. The state intervention and the increase in expenditure promise positive results in the fields of health care and education. The development of a fairer health care system is facilitated by decentralised health care and free birth mother care in all public health facilities. 
Kenya has every chance of becoming one of Africa's success stories as a result of its ever-growing young population, dynamic private sector, highly skilled workforce, better infrastructure, new constitution and the country's central role within East Africa. The most important economic and social goals are: decreasing the poverty rate and inequalities, developing governance, creating cohesion between market demand and the curriculum of education, adaptation to climate change and achieving a rapid and sustainable increase in investment and the productivity of companies.

\section{THE WORLD BANK AND KENYA}

The strategy of the World Bank Group (WBG) in terms of Kenya is to support the government's "Vision 2030" strategy to eradicate extreme poverty and increase welfare among the whole society. The Country Partnership Strategy (CPS) FY14-18 was revised in June 2017 and focuses on the development of economic competitiveness and sustainability and the protection and assistance of vulnerable people. The CPS extended to 2020 expects 1 billion USD investment by the International Development Association (IDA), the International Bank for Reconstruction and Development (IBRD), the International Finance Corporation (IFC) and the Multilateral Investment Guarantee Agency (MIGA).

IDA's current portfolio includes 35 projects with support totalling approximately 6.5 billion USD - this includes 28 national projects (5.3 billion USD) and seven regional projects (1.2 billion USD). The greatest investments are allocated for infrastructural developments, while the social sector takes the second place. Further fields supported through projects include agriculture; decentralisation; government; justice, law and order; disaster risk management; forced migration; private sector development; development of statistical capacity.

A few examples of projects accepted recently:

- Kenya Social and Economic Inclusion Project (250 million USD), providing support for poor and vulnerable households by facilitating their access to services and expanding their social safety net;

- Kenya Industry and Entrepreneurship Project (50 million USD), increasing the innovative capacities and productivity of Kenyan enterprises.

IFC's investment portfolio in Kenya amounted to 951.3 million USD on 30 June 2018. Seventy percent of this portfolio focuses on the financial sector, health care, manufacturing, services to farmers and infrastructural projects. IFC plans to improve the investment climate and provides expert advice especially in four priority areas announced by President Kenyatta: manufacturing, affordable housing, general medical care for everyone, food security. They would support access to financing, sustainable business activities, public-private partnerships (PPP) and the improvement of the investment climate by approximately 25.6 million USD.

In the framework of MIGA's portfolio, 148 million USD has been invested, providing financial resources for three projects launched in order to the private investments in the energy sector. In the near future, a major transport project worth approximately 1 billion USD and two energy sector developments are expected. MIGA works in close cooperation with a unit of the Ministry of Finance specialised in PPP matters in order to promote high priority projects, especially in the field of infrastructure development and housing. 


\section{KENYA NATIONAL INNOVATION AGENCY}

Kenya National Innovation Agency (KENIA) is a state company that belongs to the Ministry of Education, and was established under the provisions of the Science, Technology and Innovation Act. The basic role of the Agency is to develop and manage Kenya's National Innovation System. The Agency is therefore responsible for the coordination, promotion and regulation of the national innovation ecosystem.

In accordance with government policies regarding the encouragement of innovation, entrepreneurship and self-sustaining economy, the Agency works on the embedding of scientific, technological and innovation management developments in the national production system. The Agency develops and manages the Kenya National Innovation System, thus institutionalising the relationship between universities, research institutes, the private sector, government and other sectors. It draws up national standards for innovation based on international best practices, and fosters innovative ideas created by individuals, educational institutions and the private sector.

Moreover, the Agency cooperates with other relevant institutions in the creation and regular updating of an innovational database. The Agency is also going to increase the investors' knowledge and consciousness regarding intellectual property rights, create and maintain an award system to reward the development of novel innovations in a presidential or other form, and become an executive of national innovation and trade policies. The Agency incubates innovation and development projects, creating synergies.

\section{KENYA INDUSTRIAL RESEARCH AND DEVELOPMENT INSTITUTE (KIRDI)}

The Kenya Industrial Research and Development Institute (KIRDI) is a state-owned company supervised by the Ministry of Industry, Trade and Cooperatives. Its task is to research and develop industrial and related technologies in a multidisciplinary way, including mechanics, electronics, chemicals, ceramics and building materials, food, leather, textile, ICT, environment and energy. The developed technologies are handed over to micro, small and medium enterprises and large enterprises to increase their competitiveness and productivity.

The aim of Vision 2030 is to make Kenya a newly industrialising middle-income country which will be able to provide all its citizens with a high standard of living in a clean and safe environment by 2030. In order to facilitate the implementation of the strategy, KIRDI's transformation into a world-class research organization was identified as one of the priority projects of the manufacturing sector. KIRDI's transformation into a world-class research organization involves the development of the research, technology and innovation ecosystem and the skills development of human capital (scientists and engineers).

Research, technology and innovation play a key role in the achievement of the four big objectives. The increasing of the added value can only be achieved through research, product development and the application of modern production technology. Increasing the share of manufacturing industry in the GDP largely depends on the productivity and competitiveness of manufacturing industry. Productivity and competitiveness mostly depend on the type and nature of applied technology. Food security and nutrition depends on agricultural productivity and post-harvest farming, which are also largely based on technology. It is necessary to decrease 
the costs of agricultural and post-harvest machinery by producing them locally. The provision of affordable universal health care and national coverage largely depends on the availability and costs of diagnostic equipment and medicines. Producing diagnostic equipment and medicines locally increases costs, thus contributing to their availability and affordability. The provision of affordable housing mostly requires the use of innovative technologies that may decrease the costs of building materials. KIRDI develops value-added manufacturing technologies and forwards these to the SME sector. The transferred technologies increase the productivity and competitiveness of enterprises, thereby enabling them to grow, create jobs and increase their contribution to the GDP.

\section{CHANDARIA BUSINESS INNOVATION AND INCUBATION CENTRE}

The Centre aims to be an internationally recognised business innovation and incubation institution providing mentoring and encouragement for the students and employees of Kenyatta University and other Kenyan citizens, in order to make them the engine of economy and future employers.

The Chandaria Business Innovation and Incubation Centre (Chandaria-BIC) was launched in July 2011 with the mission of supporting Kenya's pioneering and innovative ideas. Its focus is to support 120 start-up enterprises each year (70\% by Kenyatta University students and $30 \%$ by external applicants). Innovators receive important services such as business development consulting, initial capital, offices, phones, high-speed internet, stationery, administrative support, professional guidance and mentoring for 12 months with an extension option. They define various milestones for each enterprise selected for participation in the programme that they have to reach in order to receive further support.

\section{REFERENCES}

Marshall, Tim (2018): A földrajz fogságában, Tíz térkép, amely mindent elmond arról, amit tudni érdemes a globális politikai folyamatokról ('Prisoners of Geography. Ten Maps That Tell You Everything You Need to Know About Global Politics"), Park, Budapest, ISBN: 9789633554111

Pasquier, Martin (2013): Africa is the Future, but their Innovation Ecosystems Need Help, retrieved: 11.04.2019., https://www.innovationiseverywhere.com/africa-future-innovation-ecosystems-need-help;

Külgazdasági és Külügyminisztérium, Külkereskedelmi Főosztály ("Ministry of Foreign Affairs and Trade, Department of Foreign Trade"), Export Hungary, retrieved: 13.04.2019, http://exporthungary.gov.hu/

The World Bank In Kenya; retrieved: 15.04.2019., https://www.worldbank.org/en/country/kenya/overview

Kenya National Innovation Agency website, retrieved: 18.04.2019., http://www.innovationagency.go.ke/

Kenya Industrial Research and Development Institute (KIRDI) website, retrieved: 19.04.2019., https://www.kirdi.go.ke/

Chandaria Business Innovation and Incubation Centre website, retrieved: 19.04.2019., http:// www.ku.ac.ke/chandaria-biic/

Kenya Physical Map, Free World Maps, retrieved: 19.04.2019., http://www.freeworldmaps.net/ africa/kenya/map.html 